\title{
INFLUENCE OF SHEAR RATE ON THE SOIL'S SHEAR STRENGTH
}

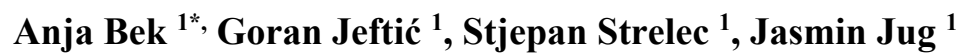 \\ ${ }^{1}$ University of Zagreb, Faculty of Geotechnical Engineering, Hallerova aleja 7, 42000 Varaždin, Hrvatska \\ *E-mail of corresponding author: anjabek08@gmail.com
}

\begin{abstract}
One of the most important mechanical properties is shear strength. It is conditioned by the value of the maximum shear stress that the soil can withstand before failure. Exceeding the shear strength causes one particle to slide next to another, causing the failure of soil. The shear strength of the soil for effective stresses is 1 a combination of drained strength parameters: internal friction angle ( $\varphi$ ) and cohesion (c) defined by the Mohr-Coulomb failure criterion. It is determined "in situ" and by laboratory experiments. Direct shear is the oldest and the simplest laboratory experiment to determine the shear strength of the soil. The first phase of experiment is specimen consolidation under specific vertical stress, and in the second phase specimens are sheared at a given shear rate, depending on the consolidation properties of the soil. Cohesionless soils are sheared at up to 100 times higher shear rate compared to cohesive soils. Shear rate and drainage conditions affect the magnitude of soil strength parameters. The paper is based on the comparison and demonstration of the influence of different shear rates on the peak and residual shear strength in the direct shear device. The tests were performed on two samples of low plasticity clay $(\mathrm{CL})$ and one sample of high plasticity clay $(\mathrm{CH})$.
\end{abstract}

Keywords: shear strength, shear rate, shear strength parameters, direct shear.

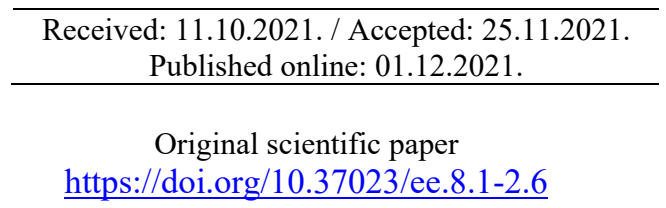

\section{INTRODUCTION}

Soil failure occurs due to exceedance of the maximum shear stress that soil can withstand, which makes shear strength highly important for the execution of both designs and construction. When testing the soil's shear strength in a direct shear device, the correct choice of shear rate is very important. Coherent soils shear at a lower rate, and the shear rate for cohesionless soils is up to 100 times higher.

This paper deals with the influence of different shear rates on the peak and residual shear strength of the soil. Increasing the dynamic load causes the soil to slide whereby residual shear strength becomes important. Two samples of low plasticity clay (CL) and one sample of high plasticity clay $(\mathrm{CH})$ were used, in a direct shear device and in consolidated drained conditions, for determining the soils shear strength; the results are presented graphically and tabulated.

\section{PREVIOUS RESEARCH}

Rouaiguia \& Rogers (2001) tested the influence of shear rate on peak and residual values of the internal friction angle and cohesion on three samples of kaolin, two samples of clay and one sample of sludge. All the tested samples showed a higher value of peak cohesion at higher shear rates when compared to lower shear rates, while the peak internal friction angle had a lower value at a higher rate.

Strength tests at three landslide sites in loess areas (Baoqi et al., 2018) showed that samples which were sheared faster also demonstrated a higher value of cohesion than at a lower shear rate. The internal friction angle value is smaller at a slower shear. Soil samples consolidated under lower vertical stress demonstrated a lower value of peak shear stress.

Papić (2014) presented a test of shear strength for two samples of mid to high-plasticity clay after compaction according to the standard Proctor experiment. The results of the conducted experiments demonstrated that a smaller normal stress leads to lower peak shear stress. Likewise, the results demonstrate that an increase in shear rate causes increase in cohesion, and a decrease of the internal friction angle.

\section{SHEAR STRENGTH}

Shear strength is the highest value of shear stress that can be applied to soil structure in a certain direction. Reaching maximum shear stress, followed by plastic deformations, leads to soil failure, with one particle sliding over another. Due to friction resistance in grain contact, the soil shows the greatest part of shear strength. If there was no friction among grains, the soil's behaviour would be the same as that of a liquid. Shear stress is taken on by the soil's skeleton, while the stress is transferred via contact forces of neighbouring 
grains. Pre-consolidated and compacted soils have characteristic peak and residual shear strengths. Loose and normally consolidated soils show peak shear strength reached after larger displacement.

\subsection{Failure creation}

Terzaghi's modification of Mohr-Coulomb failure criterion defines the shear strength of soil for effective stress (Eslami et al. 2020). Shear strength, shown in Equation 1, is defined by the parameters of drained strength - cohesion and the internal friction angle:

$$
\tau_{f}=c^{\prime}+\sigma^{\prime} \cdot \operatorname{tg} \varphi^{\prime}
$$

where $\tau_{f}$ is shear stress, $c^{\prime}$ is drained cohesion, $\sigma^{\prime}$ is defined as normal effective stress applied on the soil sample, while $\varphi^{\prime}$ is the drained internal friction angle.

Figure 1 illustrates the peak and residual strength and the failure envelope for peak and residual shear conditions.

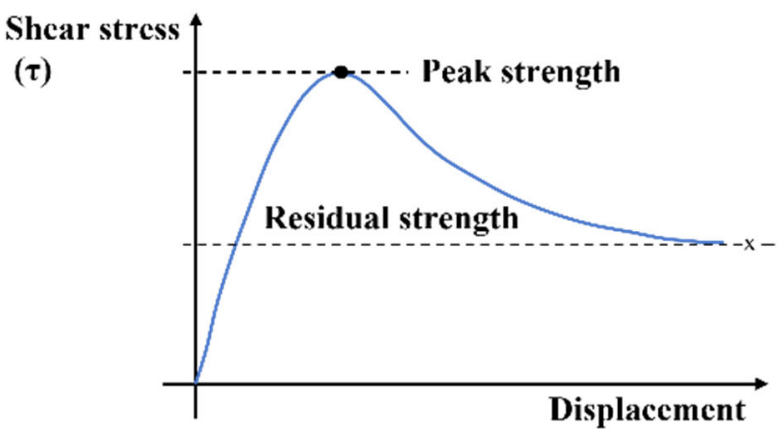

(a)

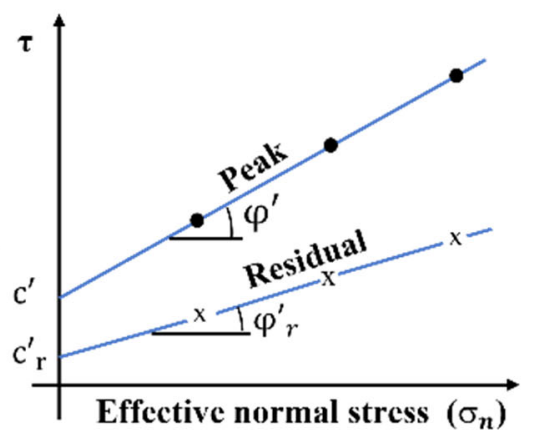

(b)

Figure 4. a) The peak and residual strength and b) the approximated failure envelope for peak and residual conditions (Head \& Epps, 2011)

\subsubsection{Cohesion and the internal friction angle}

Cohesion is a characteristic of fine-grained (coherent) soil and occurs as a consequence of electric and Wan der Waals forces applied to contact points of neighboring grains. When normal stress equals zero, the soil resists shearing due to cohesion. Cohesion is not a constant soil parameter; its value depends on water (moisture) content of soil. At higher content of moisture, the strength of electrochemical forces is lower, while it completely disappears if the soil is dissolved in water.

In gravel and sand, the internal friction angle is the natural slope angle which can withstand the slope inclination with such material. Soil compaction increases the internal friction angle, depending on particle size, porosity, and consistency state (for coherent soils). The internal friction angle has a higher value in cohesionless soils than in coherent ones (Table 1).

Table 1. Values of the internal friction angle in coherent and cohesionless soils (Geotechdata, Angle of friction)

\begin{tabular}{|c|c|c|c|c|}
\hline \multirow{2}{*}{ Description } & \multirow{2}{*}{ USCS } & \multicolumn{3}{|c|}{ Internal friction angle $\left[^{\circ}\right]^{-}$} \\
\cline { 3 - 5 } & & Minimum value & Maximum value & Specific value \\
\hline Well graded gravel & GW & 33 & 40 & - \\
\hline Poorly graded gravel & GP & 32 & 44 & - \\
\hline Well graded sand & SW & 33 & 43 & - \\
\hline Well graded sand - compacted & SW & - & & 38 \\
\hline Poorly graded sand & SP & 30 & 39 & - \\
\hline High plasticity dust & MH & 23 & 33 & - \\
\hline High plasticity clay & CH & 17 & 31 & 19 \\
\hline High plasticity clay - compacted & CH & - & - & - \\
\hline Low plasticity clay & CL & 27 & 35 & 28 \\
\hline Low plasticity clay - compacted & CL & - & - & - \\
\hline Peat and other organic soils & Pt & 0 & 10 & \\
\hline
\end{tabular}




\subsection{Drained or slow (CD) direct shear experiment}

A consolidated drained (CD) experiment is conducted on three or four specimens of the sample in two different phases. In the first phase each specimen undergoes consolidation under different vertical stress. The first vertical stress is smaller than geological, and each subsequent stress is double the value of the previous one. The second phase of the experiment is specimen shearing under constant vertical stress action.

\subsection{Shear rate}

Shear rate depends on the sample's consolidation parameters i.e., the drainage condition, permeability, and sample thickness. Sher rate must be slow enough to enable a total drainage of the sample and the dissipation of pore pressures which are not measurable within this type of test. Cohesionless soils shear at higher while coherent soils shear at a lower velocity determined by Equation 2:

$$
v=\frac{\delta_{f}}{t_{f}}
$$

where $\boldsymbol{v}$ is the shear velocity calculated as the ratio between displacement $\boldsymbol{\delta}_{f}$ and time $\boldsymbol{t}_{\boldsymbol{f}}$ necessary for failure.

\subsubsection{Displacement in failure}

Displacement at failure is an estimated value which will mobilize the peak shear strength. Table 2 shows displacement range at failure for sand and clay in a direct shear device.

Table 2. Direct shear displacement in sand and clay at failure (Head \& Epps, 2011)

\begin{tabular}{|c|c|}
\hline Soil type & Displacement [mm] \\
\hline Loose sand & $5-8$ \\
\hline Compacted sand & $2-5$ \\
\hline Plastic clay & 8 \\
\hline Rigid-plastic clay & $2-5$ \\
\hline Solid clay & $1-2$ \\
\hline
\end{tabular}

\subsubsection{Time to failure}

The time required for failure is determined from the curve of the settlement timeline, yielded during the consolidation phase. Based on the curve, it can be determined the time necessary for $100 \%$ (t100) of primary consolidation, as shown on Figure 2.

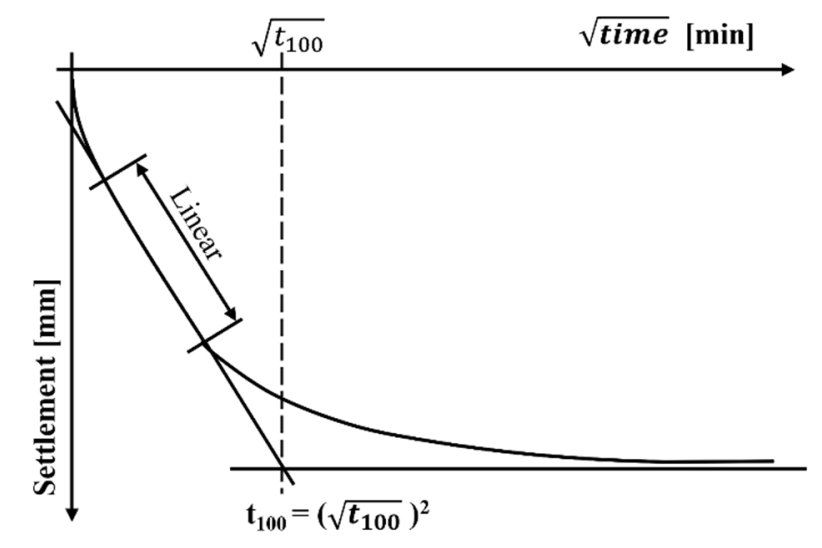

Figure 2. Graphic representation of determining time $\sqrt{\mathbf{t}_{\mathbf{1 0 0}}}$ (Head \& Epps, 2011)

The time value $\sqrt{t_{100}}$, whose square value is needed to determine time $t_{100}$, is determined in the following way: a tangent is drawn onto the straight-line part of the primary consolidation. The tangent is elongated to the intersect 
point with the horizontal line representing $100 \%$ of consolidation. The intersect point between the elongated tangent and the horizontal curve is the value $\sqrt{t_{100}}$.

The time $\boldsymbol{t}_{\boldsymbol{f}}$ necessary for failure is determined by Equation 3 (BS 1377 Part $\left.7: 1990\right)$ ):

$$
t_{f}=12,7 \cdot t_{100}
$$

\section{LABORATORY DETERMINATION OF SHEAR STRENGTH IN A DIRECT SHEAR DEVICE}

A laboratory test determined the shear strength of three soil samples. Nine test specimens were prepared from the same soil sample, three for each shear rate. The influence of different shear rates was compared and their influence on the parameters of the soil's shear strength, cohesion (c) and internal friction angle $(\varphi)$. The tests for all samples were conducted according to the norm BS 1377 Part $7: 1990$ Clause 4 - Determination of the shear strength by direct shear (small shear box apparatus). All the tests were conducted in a direct shear device in consolidated drained conditions.

\subsection{Soil sample classification}

Table 3 lists the characteristics and the classification of the tested intact soil samples, and they are featured in the plasticity chart on Figure 3.

Table 3. The classification and the characteristics of the tested soil samples

\begin{tabular}{|c|c|c|c|c|c|c|}
\hline $\begin{array}{c}\text { Sample } \\
\text { mark }\end{array}$ & Moisture & Liquid limit & Plasticity limit & $\begin{array}{c}\text { Plasticity } \\
\text { index }\end{array}$ & Consistency index & $\begin{array}{c}\text { USCS } \\
\text { classification }\end{array}$ \\
\hline & $w_{0}[\%]$ & $w_{L}[\%]$ & $w_{P}[\%]$ & $I_{P}[\%]$ & $I_{C}[-]$ & \\
\hline $\mathbf{1}$ & 24,2 & 47,5 & 20,9 & 26,6 & 0,88 & CL \\
\hline $\mathbf{2}$ & 24,6 & 45,3 & 21,2 & 25,0 & 0,87 & CL \\
\hline $\mathbf{3}$ & 38,1 & 83,3 & 34,7 & 48,6 & 0,93 & CH \\
\hline
\end{tabular}

\section{PLASTICITY CHART}

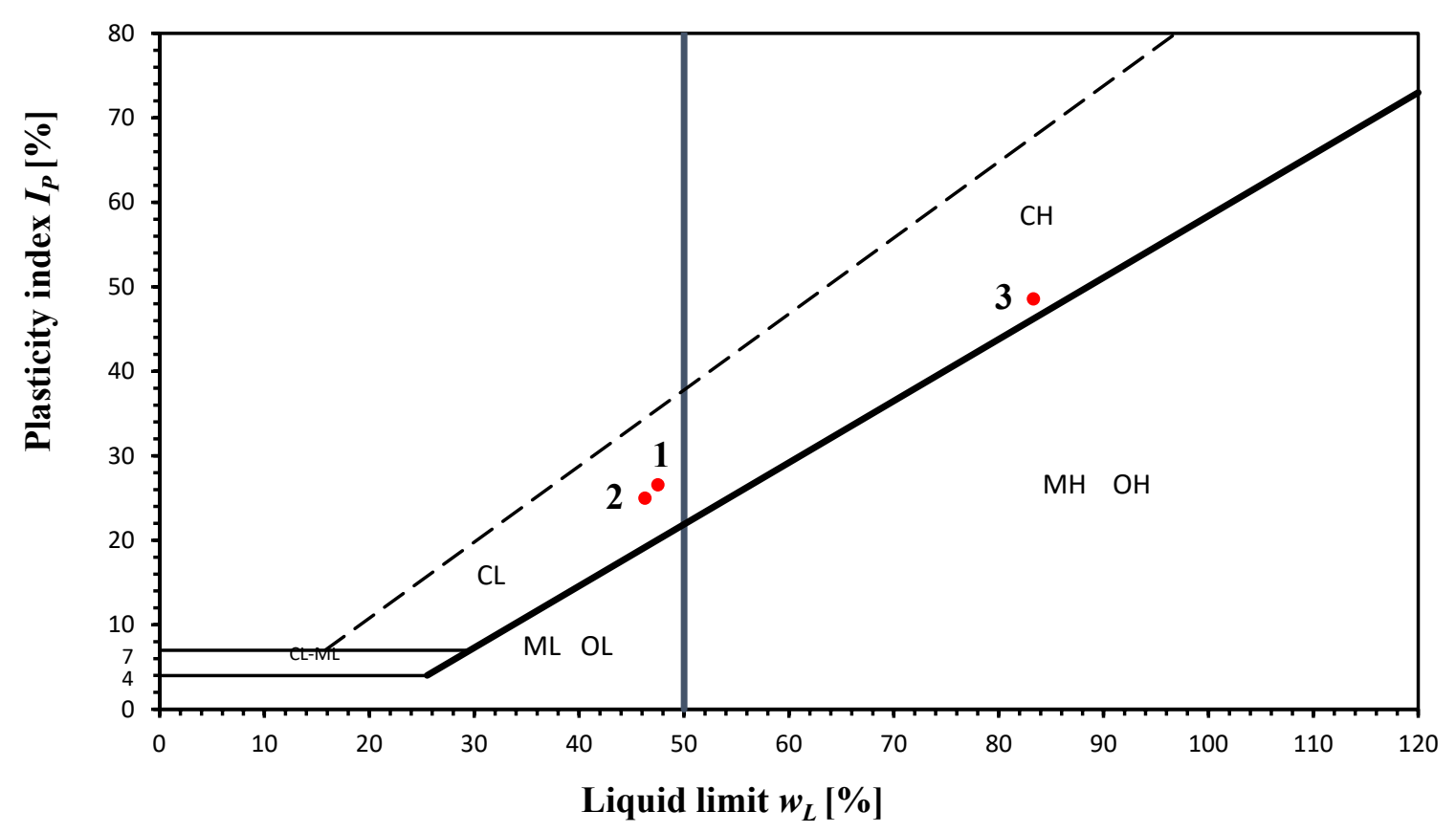

Figure 3. The plasticity chart for the tested soil samples 


\subsection{Processing and installing specimens}

Each soil sample was cut into nine smaller soil pieces - soil specimens with dimensions 60x60x20 mm; processing leftovers are left to dry to constant mass, to determine moisture.

A processed specimen (Figure 4) is installed into the shearing cell, placing two porous plates on each side of the specimen, which enable water drainage; the cell with the specimen is then placed into the direct shear device (Figure 5).

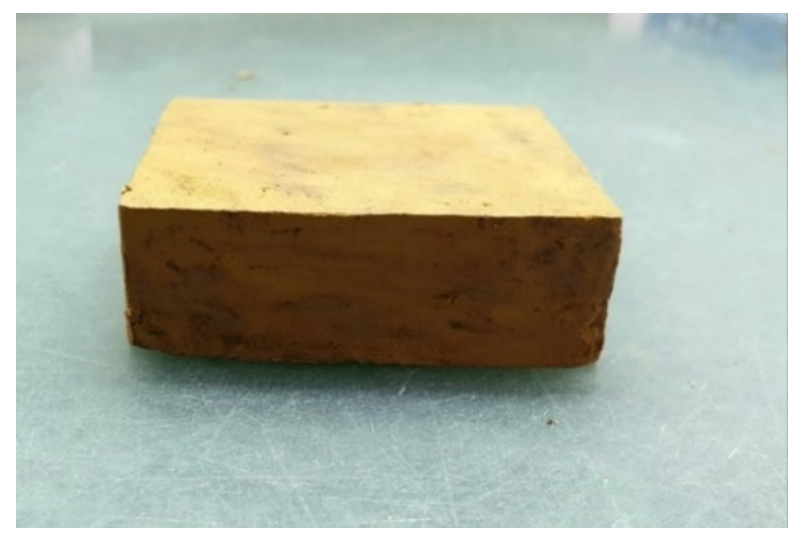

Figure 5. Specimen processed from the CL sample

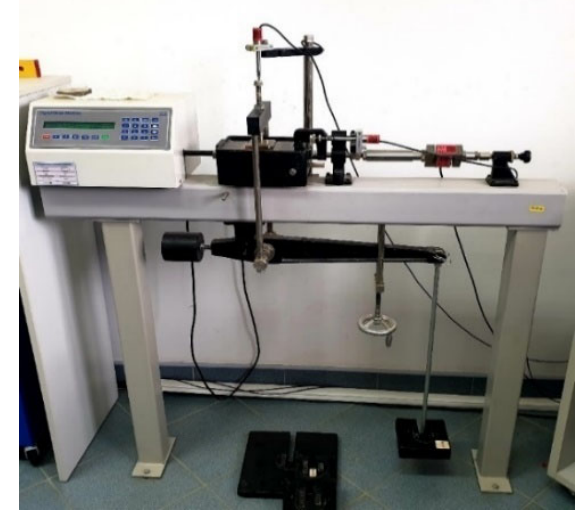

Figure 6. The direct shear device

\subsection{Testing the specimens}

Processed specimens from three soil sample are tested in two phases. The first phase is soil sample consolidation; following the consolidation completion. In the second phase the sample is sheared at a specific rate.

Groups of three specimens from each soil sample to be sheared at the same rate are consolidated under different normal stress. The first specimen is consolidated at a normal stress of $54,5 \mathrm{kPa}$, the second specimen at $109,0 \mathrm{kPa}$, and the third at $218,0 \mathrm{kPa}$. The results of the consolidation phase are entered into the chart of the settlement timeline, which is then used to determine the time necessary for total sample settlement (t_100) and the reference shear rate, in ways described in chapters 3.3 and 3.3.2.

The consolidation phase is followed by specimen shear. Groups of three specimens are sheared at the reference rate, then ten (three) times faster than the reference rate and ten (three) times slower than the reference rate.

\subsection{The results of the conducted tests}

The results yielded from a direct shear test are interpreted in the form of three charts. The first one is a curve of the settlement timeline which is not shown in the results. The second chart shows the result of direct shear test (shear stress vs horizontal displacement curve). The third shows the values of peak and residual shear stress and the accompanying vertical stress. Through all three points of testing, a regression line is drawn which determines peak and residual values of cohesion and internal friction angle. The greatest achieved value during the shear is taken as the peak value of shear stress, while the values from the almost horizontal part of the curve, towards the end of the horizontal deformation, are accepted as the value of residual shear stress. Slope and intercept of the failure envelope are shear strength parameters of soil: cohesion (c) and internal friction angle $(\varphi)$. Slope and intercept of the residual envelope are residual shear strength parameters of soil.

After conducting specimen shear tests at different rates, the data and information attained using a computer are processed by applying the appropriate computation operations, and the results are presented both graphically and tabulated. The values of peak and residual shear stress, peak and residual cohesion, and peak and residual internal friction angle, at different shear rates and for three different soil samples, were attained.

Direct shear test results at rate $0,0075[\mathrm{~mm} / \mathrm{min}]$ (sample \#3) are shown in Figure 6. Failure envelope (red line) and residual envelope (blue line) at rate $0,0075[\mathrm{~mm} / \mathrm{min}]$ (sample \#3) are shown in Figure 7. The test results of other soil samples at different shear rates are not shown graphically. The results are presented in a table (Table 4). 
Table 4. The report of all results attained in the direct shear experiment

\begin{tabular}{|c|c|c|c|c|c|c|c|}
\hline $\begin{array}{c}\text { Sample - } \\
\text { Classification }\end{array}$ & $\begin{array}{l}\text { Shear rate } \\
\text { [mm/min] }\end{array}$ & Specimen & \begin{tabular}{|} 
Vertical \\
stress \\
$\quad[\mathrm{kPa}]$
\end{tabular} & $\begin{array}{c}\text { Peak shear } \\
\text { strength [ } \\
\text { kPa] }\end{array}$ & $\begin{array}{l}\text { Residual } \\
\text { shear } \\
\text { strength }\end{array}$ & $\begin{array}{c}\text { Cohesion } \\
\text { [kPa] } \\
\text { Peak/ } \\
\text { residual }\end{array}$ & $\begin{array}{c}\text { Internal } \\
\text { friction angle } \\
{\left[^{\circ}\right]} \\
\text { Peak/ residual }\end{array}$ \\
\hline \multirow{9}{*}{$\# 1$ - CL } & \multirow{3}{*}{0,01} & $\mathbf{A}$ & 54,5 & 48,9 & 34,4 & \multirow{3}{*}{$\begin{array}{l}8,2 \\
5,2\end{array}$} & \multirow{3}{*}{$\begin{array}{l}34,7 \\
29,4\end{array}$} \\
\hline & & B & 109,0 & 79,1 & 68,8 & & \\
\hline & & $\mathrm{C}$ & 218,0 & 160,6 & 127,3 & & \\
\hline & \multirow{3}{*}{$\mathbf{0 , 0 3}$} & $\mathbf{A}$ & 54,5 & 53,0 & 44,2 & \multirow{3}{*}{$\begin{array}{l}24,7 \\
17,3\end{array}$} & \multirow{3}{*}{$\begin{array}{l}28,2 \\
23,7\end{array}$} \\
\hline & & B & 109,0 & 84,4 & 60,5 & & \\
\hline & & $\mathrm{C}$ & 218,0 & 141,0 & 114,4 & & \\
\hline & \multirow{3}{*}{0,1} & $\mathbf{A}$ & 54,5 & 58,4 & 35,8 & \multirow{3}{*}{$\begin{array}{c}31,0 \\
4,0\end{array}$} & \multirow{3}{*}{$\begin{array}{l}24,8 \\
29,1\end{array}$} \\
\hline & & B & 109,0 & 78,6 & 62,3 & & \\
\hline & & $\mathrm{C}$ & 218,0 & 133,2 & 125,9 & & \\
\hline \multirow{9}{*}{$\# 2-\mathbf{C L}$} & \multirow{3}{*}{0,001} & $\mathbf{A}$ & 54,5 & 42,4 & 37,9 & \multirow{3}{*}{$\begin{array}{c}10,7 \\
9,7\end{array}$} & \multirow{3}{*}{$\begin{array}{l}28,9 \\
27,1\end{array}$} \\
\hline & & B & 109,0 & 68,5 & 65,0 & & \\
\hline & & $\mathbf{C}$ & 218,0 & 131,9 & 121,4 & & \\
\hline & \multirow{3}{*}{$\mathbf{0 , 0 1}$} & $\mathbf{A}$ & 54,5 & 46,5 & 39,0 & \multirow{3}{*}{$\begin{array}{l}18,7 \\
15,5\end{array}$} & \multirow{3}{*}{$\begin{array}{l}25,8 \\
21,9\end{array}$} \\
\hline & & B & 109,0 & 69,4 & 56,8 & & \\
\hline & & $\mathbf{C}$ & 218,0 & 125,0 & 103,8 & & \\
\hline & \multirow{3}{*}{0,1} & $\mathbf{A}$ & 54,5 & 53,1 & 36,6 & \multirow{3}{*}{$\begin{array}{c}22,9 \\
6,1\end{array}$} & \multirow{3}{*}{$\begin{array}{l}25,5 \\
27,1\end{array}$} \\
\hline & & B & 109,0 & 68,5 & 57,8 & & \\
\hline & & C & 218,0 & 128,8 & 118,9 & & \\
\hline \multirow{9}{*}{ \#3 - CH } & \multirow{3}{*}{$\mathbf{0 , 0 0 7 5}$} & $\mathbf{A}$ & 54,5 & 36,2 & 15,4 & \multirow{3}{*}{$\begin{array}{c}21,3 \\
8,3\end{array}$} & \multirow{3}{*}{$\begin{array}{l}16,8 \\
10,7\end{array}$} \\
\hline & & B & 109,0 & 56,4 & 33,7 & & \\
\hline & & $\mathrm{C}$ & 218,0 & 86,2 & 48,0 & & \\
\hline & \multirow{3}{*}{$\mathbf{0 , 0 7 5}$} & $\mathbf{A}$ & 54,5 & 43,8 & 19,7 & \multirow{3}{*}{$\begin{array}{l}32,1 \\
10,0\end{array}$} & \multirow{3}{*}{$\begin{array}{l}13,9 \\
10,0\end{array}$} \\
\hline & & B & 109,0 & 61,7 & 29,1 & & \\
\hline & & $\mathrm{C}$ & 218,0 & 85,2 & 48,5 & & \\
\hline & \multirow{3}{*}{0,75} & $\mathbf{A}$ & 54,4 & 61,0 & 38,7 & \multirow{3}{*}{$\begin{array}{l}51,5 \\
30,3\end{array}$} & \multirow{3}{*}{$\begin{array}{c}11,5 \\
9,0\end{array}$} \\
\hline & & B & 109,0 & 75,1 & 48,0 & & \\
\hline & & C & 218,0 & 95,1 & 64,8 & & \\
\hline
\end{tabular}




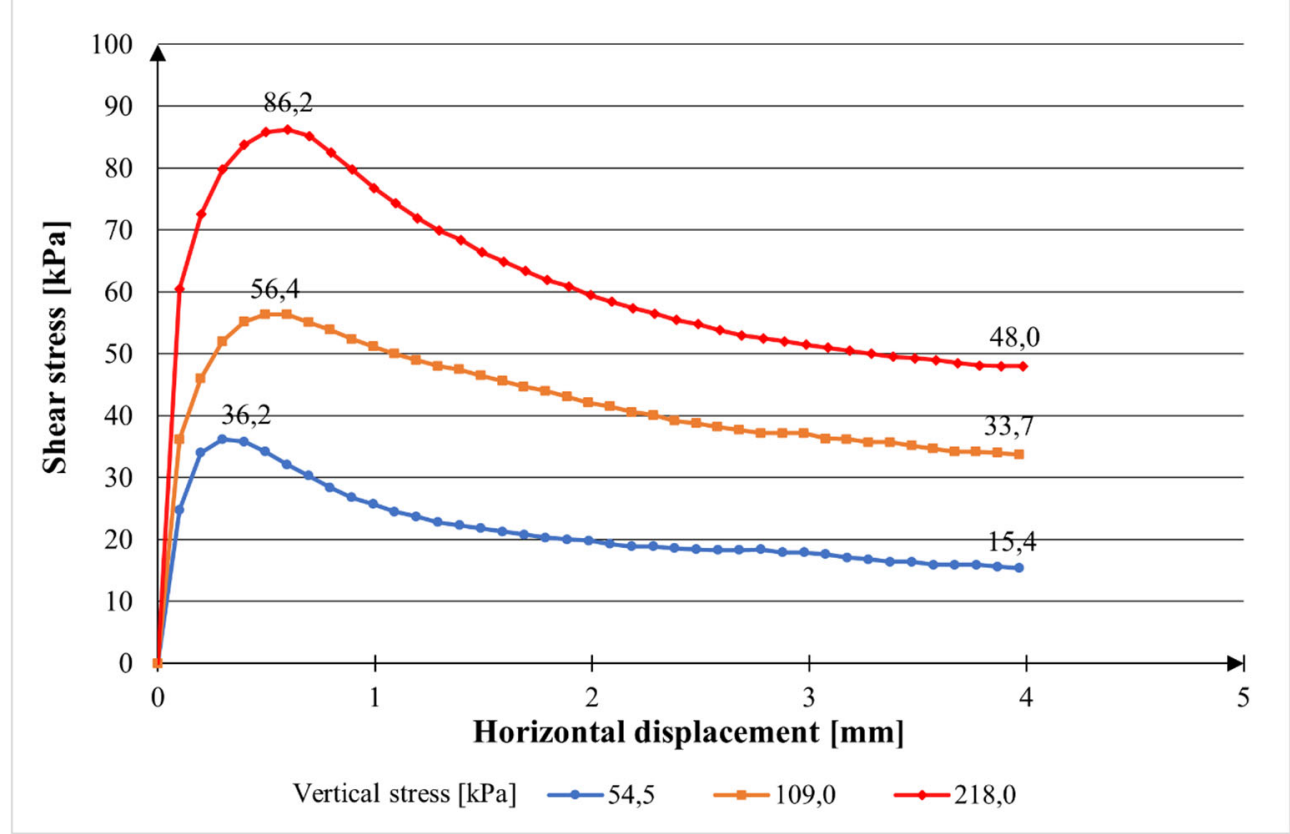

Figure 6. Direct shear rate test results at rate 0,0075 [ $\mathrm{mm} / \mathrm{min}]$ (sample \#3)

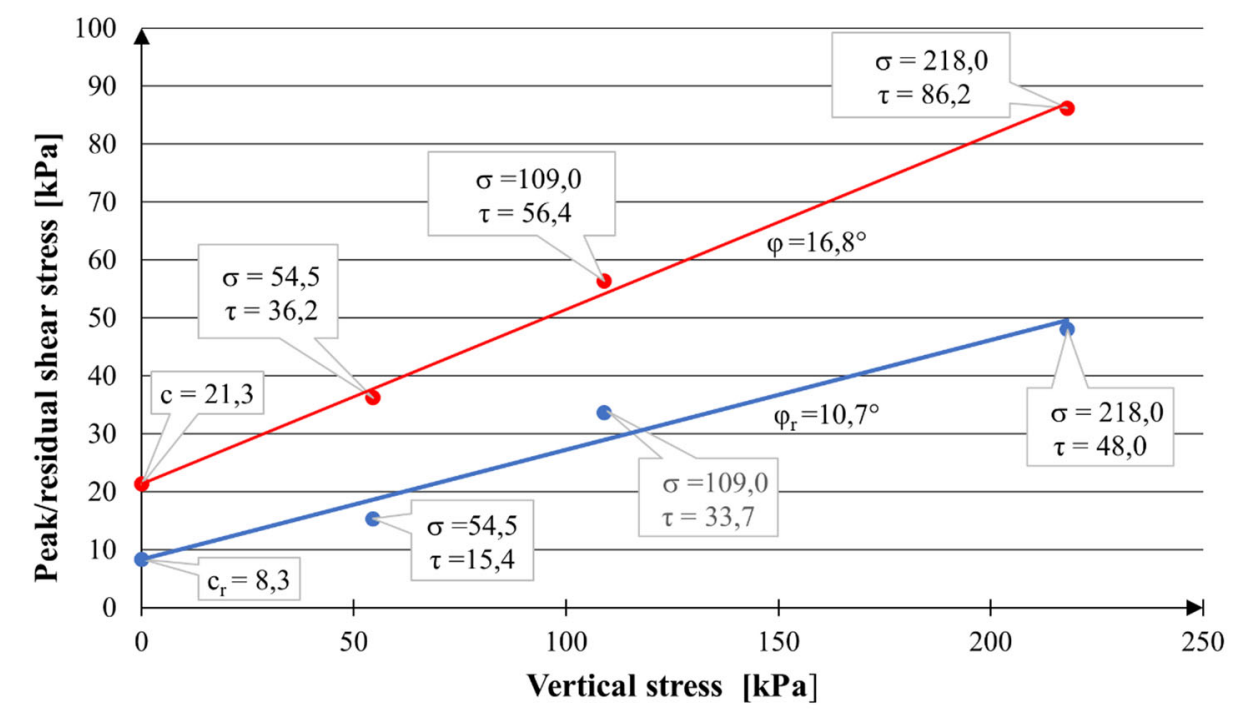

Figure 7. Failure envelope (red line) and residual envelope (blue line) at rate 0,0075 [mm/min] (sample \#3)

\subsubsection{Aggregate visualization of the direct shear experiment results}

Shown here are the failure and residual envelopes for different shear rates, in a chart of peak/residual shear stress and vertical stress for teste soil samples. The full lines represent the yielded peak values at different shear rates, and the interrupted lines represent the residual values (Figure 8, Figure 9, and Figure 10). 


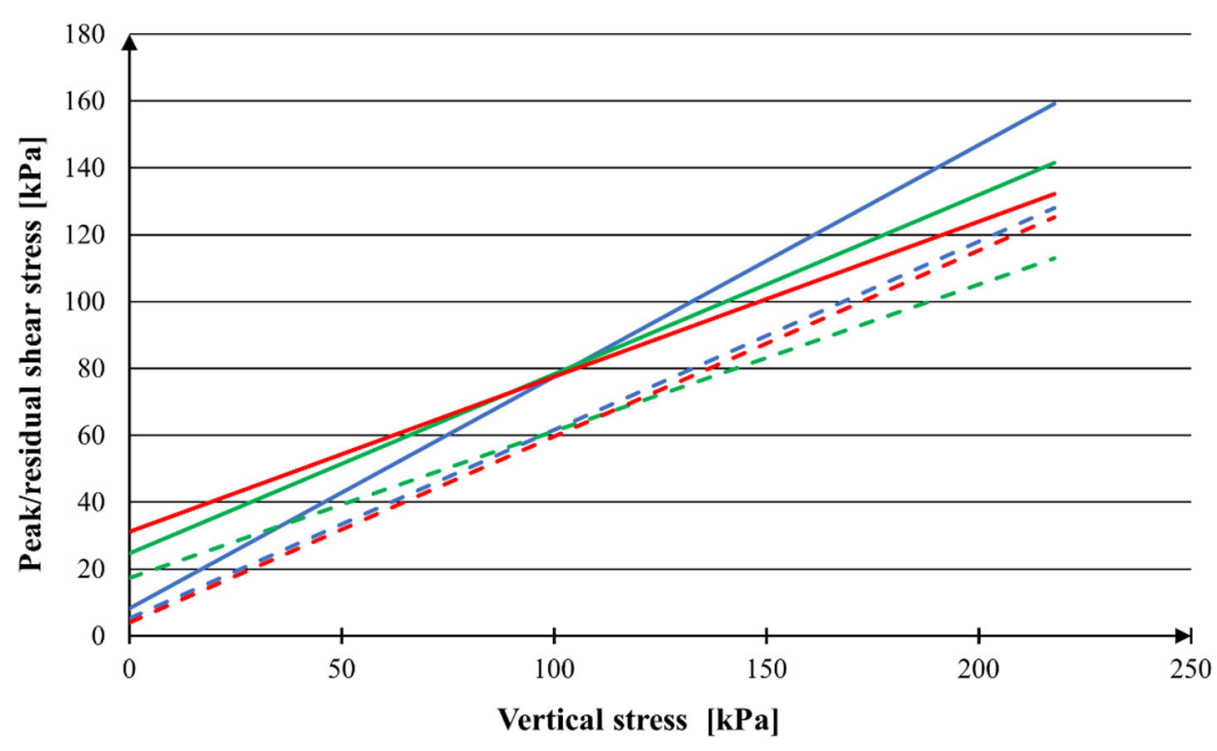

Shear rate $[\mathrm{mm} / \mathrm{min}] \quad 0,01 \bullet 0,03 \quad \bullet 0,1$

Figure 8. Failure and residual envelopes for sample \#1

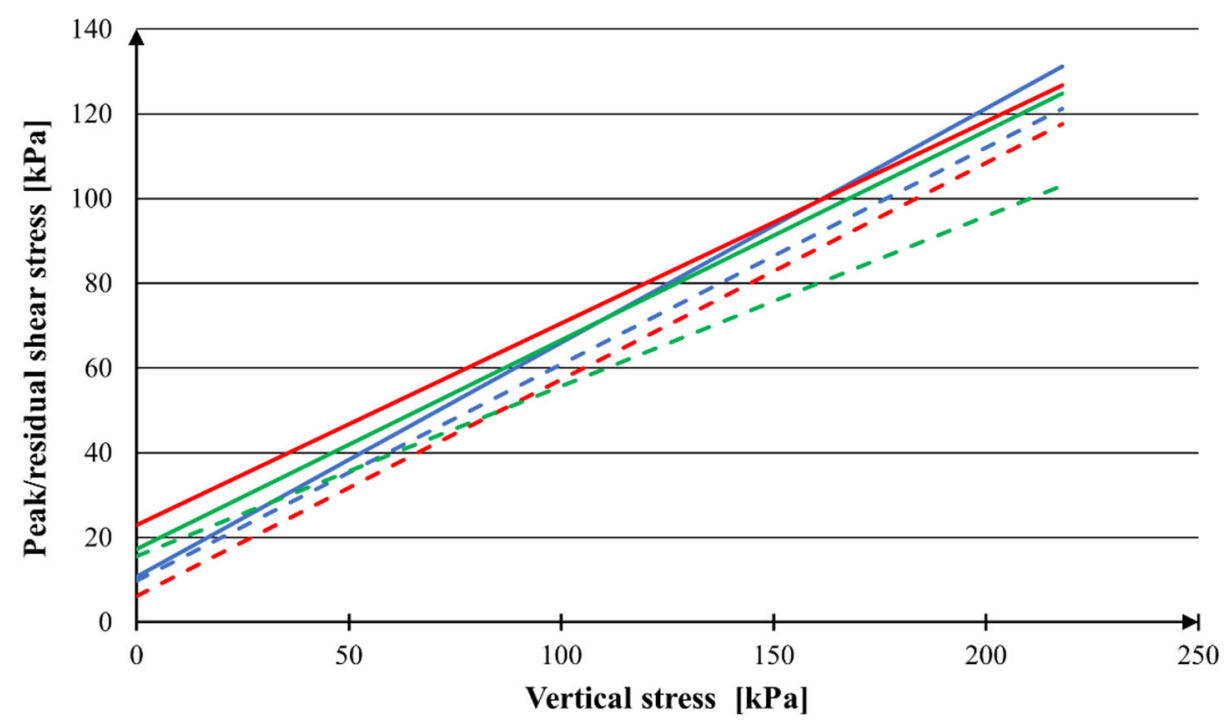

Shear rate $[\mathrm{mm} / \mathrm{min}] \quad 0,001 \quad 0,01 \quad \bullet 0,1$

Figure 9. Failure and residual envelopes for sample \#2 


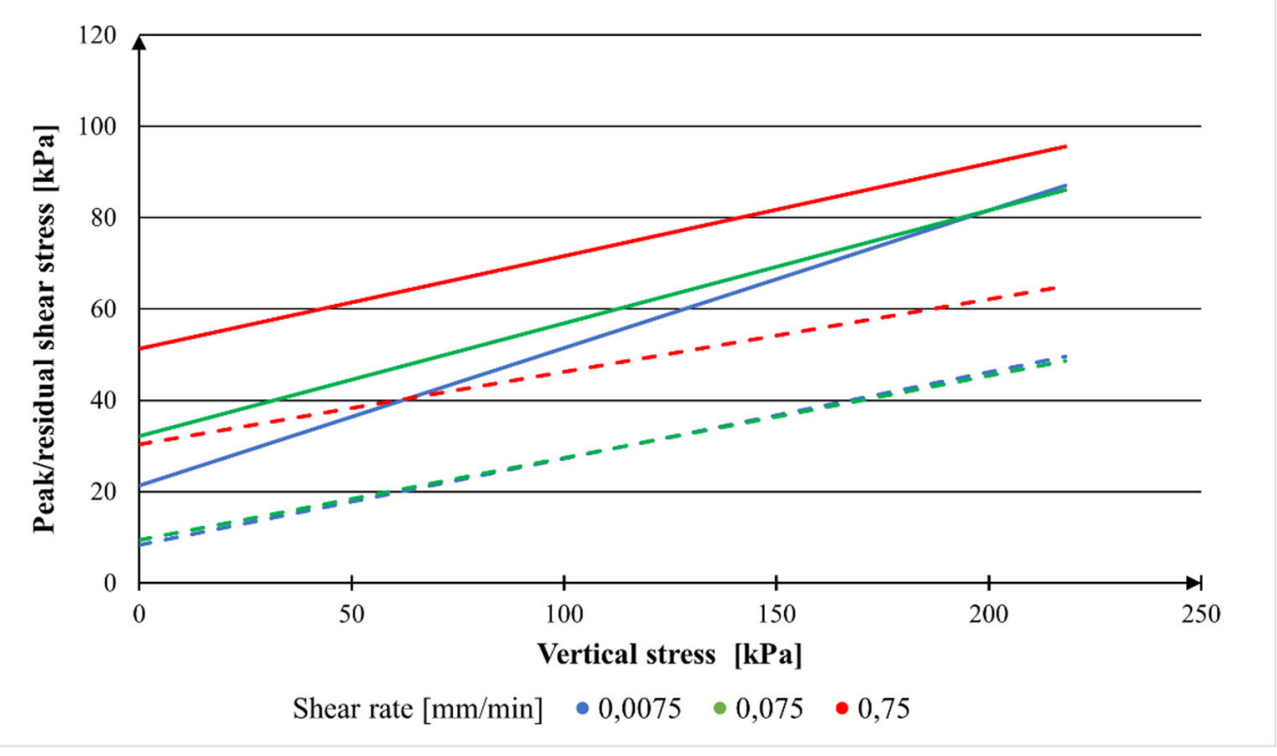

Figure 10. Failure and residual envelopes for sample \#3

\section{CONCLUSION}

The results of the laboratory soil test in a direct shear device demonstrate that the parameters of shear strength of soil do not have a constant value, but depend on soil characteristics, drainage conditions, the amount of vertical stress and shear rate. Test conditions must be chosen in a way that they approximate the actual conditions of the sample as close as possible, for the results to be as accurate as possible.

The specimens of low-plasticity clay in sample \#1 were sheared at the reference rate, three times slower and three times faster. The specimens from soil sample \#2 and soil sample \#3 were sheared at the reference rate, ten times faster and ten times slower. The conducted tests of the influence of different shear rates on the shear strength of coherent soil demonstrate that increases in shear velocity increase cohesion and decrease the internal friction angle. If shear rate is too high, the dissipation of pore pressure becomes impossible i.e., there is excess pore water pressure; the test results can lead to bigger construction costs. In the case of a too low shear rate, the result can be unrealistically favourable, which does not benefit the required safety. For these reasons, the choice of appropriate shear rate is of paramount importance.

\section{REFERENCES}

Rouaiguia, A., Rogers C.D.F.(2001), Fast shear rate effects on the residual shear strength of clay, International Society for Soil Mechanics and Geotechnical Engineering, UK, 261-264

Baoqi, L., Jianbing P., Xingang, W., Qiangbing, H., (2018), Influence of shearing rate on the residual strength characteristic of 2 three landslide soils in loess area, Discussions, X'ian-China

Bek, A., (2020), Utjecaj brzine smicanja na posmičnu čvrstoću tla, Završni rad, Sveučilište u Zagrebu, Geotehnički fakultet; Varaždin

BS 1377 Part $7: 1990$ Clause 4 - Determination of the shear strength by direct shear (small shear box apparatus)

Eslami., A., Moshfeghi, S.,MolaAbasi, H., Eslami M.M. (2020) Piezocone and Cone Penetration Test (CPTu and CPT) Applications in Foundation Engineering, First edition

Geotechdata, Angle of friction, available at: http://geotechdata.info/parameter/angle-of-friction

Head K.H, \& Epps R. J., (2011), Manual of soil laboratory testing, Volume 2: Permeability, Shear Strength and Compressibility tests, Third edition

Huđek, D.,(2008), Utjecaj brzine posmika na parametre čvrstoće tla, Diplomski rad, Sveučilište u Zagrebu, Geotehnički fakultet; Varaždin

Strelec S., Štuhec D. (2011), Geotehnički laboratorij i primjena u inženjerskoj praksi, Interna skripta, Varaždin: Sveučilište u Zagrebu, Geotehnički fakultet

Papić., M. (2014), Ovisnost posmične čvrstoće koherentnog tla o brzini smicanja, Završni rad, Sveučilište u Zagrebu, Rudarsko-geološko naftni fakultet; Zagreb 